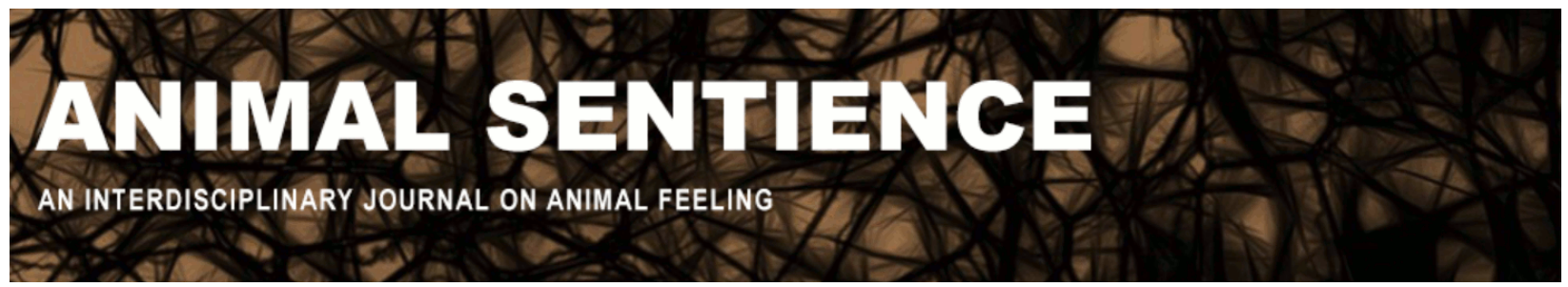

Wyatt, Tanya (2020) Harm, Earth Jurisprudence and human/nonhuman relationships. Animal Sentience 30(15)

DOI: $10.51291 / 2377-7478.1646$

Date of submission: $2020-09-11$

Date of acceptance: 2020-09-11

(c) (†)

This article has appeared in the journal Animal

Sentience, a peer-reviewed journal on animal

cognition and feeling. It has been made open access,

free for all, by WellBeing International and deposited

in the WBI Studies Repository. For more information,

please contact

wbisr-info@wellbeingintl.org.

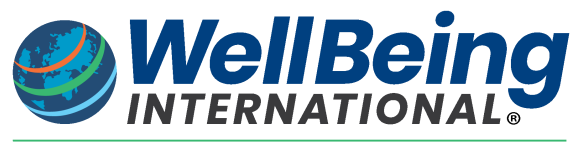

SOLUTIONS FOR PEOPLE, ANIMALS AND ENVIRONMENT 


\title{
Harm, Earth Jurisprudence and altering human/nonhuman relationships
}

Commentary on Wiebers \& Feigin on Covid Crisis

\author{
Tanya Wyatt \\ Department of Social Sciences, Northumbria University
}

\begin{abstract}
To prevent the next pandemic and to protect the environment and nonhuman animals, there needs to be a clear definition of harm and a legal system grounded in Earth Jurisprudence. Drawing on evolutionary principles to redefine harm and to radically alter the legal system to be Earth-centred will help ensure that harmful actions like certain wildlife trade, wildlife trafficking, and intensive farming do not threaten the survival of any life.
\end{abstract}

Tanya Wyatt, Professor of Criminology, Northumbria University, is a green criminologist specialising in wildlife trafficking, nonhuman animal abuse, and their intersections with organised crime, corporate crime, and corruption. Website

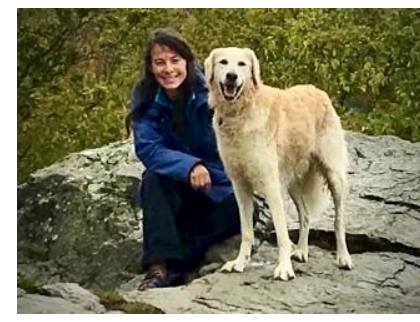

1. Human/nonhuman relationships. In their target article, Wiebers \& Feigin's (2020) (W\&F) analyse the human behaviours that have likely led to the current pandemic and the behaviours that have the potential to create future pandemics. W\&F point to the wild animal trade, particularly the live trade, intensive 'livestock' farming, the close confinement of these nonhuman animals and the associated antibiotic resistance, and the numerous extinctions that are looming from habitat incursion and destruction. Changing these behaviours requires altering humans' interaction with wildlife and the natural world, as Eshel (2020) highlights, though this is obviously difficult (Fawcett 2020). Instead of the global capitalist system that dominates much of the world and commodifies life, we-as a species and a global community-urgently need to find a basis for an altered human/nonhuman relationship. Yet it is hard to find the right way forward when all choices and changes lead to harm for humans or other species. In the first instance, I suggest we need to have a better understanding of harm and of crime. Then, we need to adopt a new legal system that supports this (new) relationship.

2. Of harm and of crime. In 1859, John Stuart Mill proposed the 'harm principle', which stated that only actions that harm others can be prevented by the authorities; otherwise individuals should have the freedom to do as they please. 'Others' only included humans (Chapman \& Huffman 2018). As Harcourt (1999) has noted, the harm principle quickly collapsed without an agreed-upon definition of harm and because of the power struggles of various interest groups vying for control over the formal (legal) definition of harm, which is what crime is (as in prohibiting actions such as alcohol and drug use). It is critical for the survival of human society and for other life on the planet that the actions W\&F discuss are defined as harm, so these actions can be regulated and/or criminalised.

To move society in this direction, Gibney \& Wyatt (2020: 11) propose a new definition of harm drawing on evolutionary principles: harm is 'that which makes the survival of life more fragile'. Life is all life, so not just humans. Grounding harm in an evolutionary timescale and in evolutionary relationships is intended to help move human society away from the focus on short-term gain, from neglecting of the negative consequences of human actions for other 
beings (Broom 2020), and from according priority to human profit and productivity (Fox 2020). An evolutionary perspective on harm recognises that humans are a part of nature. $A$ clear understanding of harm then provides the basis for regulation or criminalisation that would underpin changes to human behaviour around the consumption, trade, trafficking and farming of nonhuman animals as well as the human destruction of ecosystems and habitats (Treves et al.2019)

3. Earth Jurisprudence and Wild Law. To protect the environment and nonhuman animals and to improve nonhuman animal welfare, it would likely not be enough to simply alter the existing legal system. At least in the Western context, the environment and nonhuman animals are mostly defined as property (Nurse \& Wyatt 2020). Something much more radical is needed to "recognise all members of the Earth community as subjects before the law" and to ensure "human governance systems at all times take account of the interests of the whole Earth community"; these tenets are embedded in one of the principles of Earth Jurisprudence or Wild Law as laid out by Cullinan (2011: 13). Whilst Earth Jurisprudence principles may appear new, they are in fact inherent in many indigenous communities, who have always recognised humans as a component of nature, one member of the Earth community (Humphreys 2017). This means that there are existing human communities from which expertise and knowledge can be shared to make this radical shift (Baker \& Winkler 2020).

4. Summary. We humans must change our interactions and relationships with the environment and nonhuman animals to avoid further pandemics, and also to survive in the longer term. We must recognise that the dominant current system is harmful, because it threatens the survival of ourselves, other beings, and the planet. The legal and criminal justice systems have a sometimes-overlooked role to play in facilitating the changes we make to our actions and relationships. Limiting wildlife trade and markets, ending intensive farming, improving nonhuman animal welfare, and decreasing habitat incursion and destruction will all require a new legal infrastructure. An Earth Jurisprudential infrastructure would best support the survival of all life. Furthermore, an interdisciplinary approach-of not just natural scientists and conservationists but also social scientists, such as criminologists, economists, and psychologists-is crucial to success in making the radical changes that all species and the planet need.

\section{References}

Baker, Liv \& Winkler, Rebecca (2020) Asian elephant rescue, rehabilitation and rewilding. Animal Sentience 28(1)

Broom, Donald M (2020) The necessity of human attitude change and methods of avoiding pandemics. Animal Sentience 30(7)

Cao, Deborah (2020) Global risks of intensive animal farming and the wildlife trade. Animal Sentience 30(2)

Chapman, Colin A. \& Huffman, Michael A. (2018) Why do we want to think humans are different? Animal Sentience 23(1)

Cullinan, Cormac (2011). A history of wild law. In Exploring wild law: The philosophy of Earth jurisprudence (Peter Burdon (Ed)). Wakefield Press: pp. 12-23. 
Fawcett, Anne (2020) One Welfare, the role of health professionals, and climate change. Animal Sentience 30(9)

Fox, Michael W. (2020) One planet, one health. Animal Sentience 30(6)

Gibney, Edward \& Wyatt, Tanya (2020) Rebuilding the Harm Principle: Using an Evolutionary Perspective to Provide a New Foundation for Justice. International Journal of Crime, Justice and Social Democracy. 9(3): 100 - 115.

Harcourt, Bernard E (1999) The collapse of the harm principle. Journal of Criminal Law and Criminology. 90: 109-194.

Humphreys, David (2017) Rights of Pachamama: The emergence of an Earth jurisprudence in the Americas. Journal of International Relations and Development. 20(3): 459-484.

Mill, John Stuart (1859) On Liberty. Oxford University Press.

Nurse, Angus \& Wyatt, Tanya (2020) Wildlife Criminology. Bristol University Press.

Treves, Adrian; Santiago-Ávila, Francisco J.; and Lynn, William S. (2019) Just preservation. Animal Sentience 27(1)

Wiebers, David \& Feigin, Valery (2020) What the COVID-19 crisis is telling humanity. Animal Sentience 30(1) 